\title{
Justice and flood risk management: reflecting on different approaches to distribute and allocate flood risk management in Europe
}

\author{
Thomas Thaler ${ }^{1,2} \cdot$ Thomas Hartmann $^{3}$
}

Received: 2 December 2015/Accepted: 16 March 2016/Published online: 24 March 2016

(C) The Author(s) 2016. This article is published with open access at Springerlink.com

\begin{abstract}
This paper compares the inherent notions of justice in four different approaches to flood risk management in Europe. As protection against flood risks becomes increasingly difficult, dilemmas of justice emerge: some benefits from flood protection measures whereas others loose. Decisions on whom to protect differentiate between upstream and downstream or left and right side of a river. This raises a central but barely discussed conflict: what (or rather who) should be protected against inundations? This question deals in essence with justice. Justice concerns questions over fairness in the allocation of resources, capital and wealth across different members of society. There are different and contradicting concepts of justice, which differ in interpretations of fair resource allocation and distributions. 'What's the right thing to protect' is thus a question of concepts of justice. This contribution is not an attempt to answer this fundamental question, but it offers a debate on how different concepts of justice provide different answers. These answers will then be related to flood risk management approaches in England, the Netherlands, Germany, and Austria.
\end{abstract}

Keywords Flood risk management · Policy · Property rights · Justice · Allocation · Distribution

\section{Introduction: what should be protected?}

Protection against flood risks is becoming increasingly difficult. Not only is the likelihood of floods increasing (IPCC 2012), but, due to continuing settlement and the resulting higher degree of vulnerability in floodplains, it becomes more and more difficult to protect all

Thomas Thaler

thomas.thaler@boku.ac.at

1 Flood Hazard Research Centre, Middlesex University, London, UK

2 Institute of Mountain Risk Engineering, University of Natural Resources and Life Sciences, Vienna, Austria

3 Urban and Regional Research Centre Utrecht (URU), Utrecht University, Utrecht, The Netherlands 
properties along a river with the same standard-for economic and also for hydrological reasons (Fuchs 2009; Fuchs et al. 2015). This goes beyond the question of where to locate dikes and how high they need to be.

Flood protection measures - especially but not only dikes-influence property values, because, with their establishment, the land becomes more profitable for uses that would not have been possible without high design level (Tempels and Hartmann 2014; Hartmann and Spit 2015). Is such value increase just a windfall gain for landowners? Barraqué explains that providing flood protection means socially reinterpreting floods: they are no longer a force majeure - an act of God-but instead an issue of the welfare state (Barraqué 2014). Several questions can arise in response to this: Should a commercial area be inundated more often than a residential area, or vice versa? What is the right level of protection for cultural heritage buildings or other public buildings? Also financing flood risk management brings with it the following issues: How should flood protection affect (tax)payers who do not live in risk areas (intragenerational generation). How will policy instruments of adaptation and mitigation strategies affect future generations (intergenerational generation) (Walker 2009; McKinnon 2009; Moellendorf 2009; Neal et al. 2014). These issues of justice are barely discussed in the scholarly debate on flood risk management (Doorn 2015). Therefore, key questions surrounding those problems include the following: What justifies the protection of a particular piece of land? Whose land should be protected? Should flood risk management protect the upstream and sacrifice the downstream, or vice versa? Who- or rather what—should be protected best? These questions are recognised by recent policy, although they are not expressed in such sharp terms.

The European Floods Directive (EC 2007) requires member states of the European Union to develop flood risk management plans. These plans must be in effect by 2015 and set 'appropriate objectives for the management of flood risk and [reduce] potential adverse consequences of flooding for human health, the environment, cultural heritage and economic activity' (EC 2007). The directive requires that different scenarios be taken into consideration. This means that spatial planners, rather than considering one line of defence, must integrate various lines - this change moves the emphasis from security towards risk (Hartmann and Jüpner 2014; Thaler 2014). This has crucial consequences for the allocation of land use since it balances flood risk on a much more differentiated level, raising questions such as whether a commercial area might be inundated more often than a residential area or what might be the right level of protection for cultural heritage (Hartmann and Jüpner 2013). Different countries have found different answers to these questions about allocation principles and processes and the distribution of costs and liabilities. These answers are not always connected to the geological or geomorphological conditions (Mazzorana et al. 2012). One could argue that the Dutch Water Boards emerged as a result of their location in a Delta area, whereas the North Rhine Westphalian Water Boards can be traced back to industrialisation. However, the allocation and distribution principles are not derived from environmental condition per se; rather they are a social construction. Discussion and implications of justice in flood risk management literature is scarce (Johnson et al. 2007; Doorn 2015). With this paper, we aim to address this gap. We compare four European countries (Austria, Germany, England and the Netherlands) in terms of their answers to these questions of flood risk management. These four countries have been selected for this study because their approaches cover a sizeable variety of different concepts of justice.

This paper is divided into two main parts. The first part provides a short overview and analysis of the existing literature, which provides the context for the development of an analytical conceptual framework. The second part analyses and assesses empirical results. The empirical results demonstrate the different uses of justices' arrangement in flood risk management. 


\section{Concepts of justice}

Different schools of thought have produced different concepts of justice (Elster 1992; Mill 2010; Patrick 2014). At its most basic level, the type of justice discussed in this article concerns questions of allocation and distribution of resources and, further, capital and wealth across different members of society. Varying concepts of justice differ in their interpretations of fair resource distribution (Varian 1975). In the discussion of justice and flood protection, not only the actual allocation of flood protection measures is significant (Campbell 2012; Neal et al. 2014), but also the way in which this allocation is achieved. Justice also relates to the process by which a certain distribution is selected (procedural justice) (Johnson et al. 2007; Walker and Burningham 2011; May and Morrow 2012; Patrick 2014). However, justice in flood risk management demands more than just a fair socio-economic distribution or recognition of cultural circumstances (Zwarteveen and Boelens 2014); it has to consider geohydrological, climatological, and socio-technical aspects as well as legal cultural regulations (Zwarteveen and Boelens 2014).

Important concepts of justice include utilitarianism, libertarianism and egalitarianism (Hayek 1991; Rawls 2005; Mill 2010; Sen 2010). Each concept has implications for the allocation principles and processes and for the distribution of costs and liabilities of flood risk management. Therefore, in the following sections, we will briefly describe the basic rationales of each of these three concepts.

\subsection{Utilitarianism (maximise utility)}

According to the concept of utilitarianism, developed by classical economists Mill and Bentham, justice and equity are the sum of individual benefits. Utilitarianism tries to understand how to maximise happiness (utility) in a society (Johnson et al. 2007; Mill 2010). In fact, the main focus is the benefit of each individual. The utilitarian concept of utility involves two main outcomes: (1) pleasure (positive reaction) and (2) pain (negative reaction). Between both concepts, there is a neutral (indifferent) outcome (Elster 1992). A utilitarian policy discussion would ensure a maximal benefit to society, or in other words, the 'greatest benefit to the greatest number' (Hunold and Young 1998, p. 84).

In flood risk management, utilitarianism leads to criteria that secure the greatest risk reduction per unit of resource input. Flood risk management strategies are applied to those areas within a country where the benefits offer the greatest gain to the society (Johnson et al. 2007). In sum, the distribution principle is the aggregated utility function of individual well-being, where the role of the state is to ensure individual freedom and individualism (Mill 2010). A typical tool to assess what should be protected and what should not is the cost-benefit analysis (CBA).

\subsection{Libertarianism (individual responsibility)}

The main principles of libertarian justice are free market principles, especially competition, availability of full information, equilibrium in market process and freedom of individual self-decision (economic freedom) (Hayek 1991; Johnson et al. 2007). According to Hayek (1991), the key aspects are the availability of full information and pre-defined rules (e.g., compensation payments). The distribution principle relies on the freedom of choices and the invisible hand of the market, whereas the role of the state is to define rules for individual action (Ostrom 1986; North 1990). Rules are the basic instrument for regulating 
individual freedom and relationships within the society (Ostrom 1986). Rules can be seen as 'prescriptions commonly known and used by a set of participants to order repetitive, interdependent relationships' (Ostrom 1986, p. 5). Key objectives of rules are to define the interaction with the objective of individual freedom (North 1990).

Libertarian flood risk management entails a limited influence of the public government on flood risk management. It is organised by the market forces, which means that they facilitate insurance schemes or provide information on flood hazards zones. Libertarianism promotes non-governmental activities in adaptation instead of public flood risk management.

\subsection{Egalitarianism (maximise rule and equality)}

Main focus of egalitarian principle is on equal and fair distribution of goods, services, and burdens between citizens (equally between all citizens). 'Goods ought to be divided equally among everybody. Even when there is no consensus that equality is inherently fair, it is often the only focal point for the resolution of conflicts' (Elster 1992, p. 70). The key argument is to ensure the equal opportunity of each citizen in the policy process (procedural justices). Main critiques are the aspect that different citizens need different resources to achieve the same targets and objectives (Roemer 1987). Rawls (2005) posited justice as a concept that is defined by society to ensure basic needs and equality in terms of rights and duties (maximise rule). Based on this understanding, Rawls justifies inequalities 'only when it is necessary to avoid an even greater injustice' (Rawls 2005, p. 4). He tolerates injustices if unequal developments in the society increase the overall benefit (wealth) of the society. If the outcome reflects injustice, individuals will not be punished or discriminated against in another aspect (Zwarteveen and Boelens 2014). In sum, the Rawlsian concept of justice focuses on the distribution of primary goods as a central precondition of equality instead of the power relationship between the different actors and stakeholders in the decision-making process (Johnson et al. 2007; Lu et al. 2014).

For flood risk management, egalitarianism posits that the distribution of flood risk management strategies and implementations should be addressed to the most vulnerable people and objectives, such as implementing flood storages in the upper part of the catchment principle to protect downstream communities (Johnson et al. 2007; Thaler 2014). The key aim is to analyse the social capacity of individuals referring to flood risk management events (Gardoni and Murphy 2009). The concept focuses on vulnerability reduction and public-funded flood risk management strategies for communities who were disadvantaged. Therefore, it requires that flood risk management strategies should target at the most vulnerable people with the key objective of funding local self-help adaptation strategies, since large-scale investments cannot justify local flood risk management strategies. The key objective is to avoid favouring high-value assets and areas within the country when selecting flood risk management strategies (Johnson et al. 2007).

\section{Conceptual framework}

To translate and analyse justice discourse within flood risk management, a heuristicanalytical framework (Table 1) is used. In sum, the table compares the implications of the three main justice principles for flood risk management. The actual measures of flood risk management in the four countries will be compared based on the following questions:

- What are the allocation principles for flood protection measures? 
- How is the process for the allocation organised?

- How are measures financed?

- Who is liable (and pays) for damage incurred by flood events?

These questions will be evaluated according to the prevalent concept of justice in the respective countries. To accomplish this, a qualitative assessment of the basic principles and theories of justice must be applied.

\section{Method}

The research method applied in this paper focuses on qualitative research. The aim is to adopt different theoretical concepts and methods, such as policy analysis as well as semistructured in-depth interviews. The key objective is to generate or to redefine theoretical concepts and discussions and not to test theoretical concepts and ideas (Mabry 2009). For this purpose, we analyse policy documents, laws and the literature of the four countries. As a first step, all relevant data-like research papers, consultant reports, reports, statement and acts from public authorities, press articles and online websites - must be gathered. This analysis is not meant to represent all the details of the countries' flood risk management approaches and policies - such an analysis would be a Herculean task. Rather the aim of this paper is to identify the underlying notions of justice behind the predominant instruments of flood management in each of the four countries. The results will then be assessed in comparison with and juxtaposition to each other. The analysis has been complemented by semi-structured interviews and discussions with experts in the different countries. We conducted a series of semi-structured interviews with representatives from national, regional and local authorities.

\section{Results}

Due to the actual economic and financial crises as well as technical limitations, protection against flood risks becomes increasingly difficult. Therefore, not all properties along a river can be protected with the same standard. This raises a central yet barely discussed issue of

Table 1 Justice principles for flood risk management

\begin{tabular}{|c|c|c|c|}
\hline & Utilitarianism & Libertarianism & Egalitarianism \\
\hline $\begin{array}{l}\text { Allocation of } \\
\text { flood } \\
\text { protection } \\
\text { measures }\end{array}$ & $\begin{array}{l}\text { Differentiated } \\
\text { protection } \\
\text { standards based } \\
\text { on CBA ratio }\end{array}$ & $\begin{array}{l}\text { Local and individual } \\
\text { protection measures }\end{array}$ & $\begin{array}{l}\text { Equal protection standards } \\
\text { for all }\end{array}$ \\
\hline $\begin{array}{l}\text { Process of } \\
\text { allocation }\end{array}$ & $\begin{array}{l}\text { Expert-based } \\
\text { decision-making }\end{array}$ & $\begin{array}{l}\text { Process of allocation is } \\
\text { based on a market system }\end{array}$ & $\begin{array}{r}\text { Consensus on general } \\
\text { protection standards }\end{array}$ \\
\hline $\begin{array}{l}\text { Share of costs } \\
\text { for flood } \\
\text { protection }\end{array}$ & $\begin{array}{l}\text { Public funding } \\
\text { based on } \\
\text { calculated fees }\end{array}$ & Private-private partnerships & $\begin{array}{l}\text { General public budget } \\
\text { (i.e., tax-financed) }\end{array}$ \\
\hline $\begin{array}{l}\text { Liability of } \\
\text { damage }\end{array}$ & $\begin{array}{l}\text { Clear } \\
\text { responsibilities } \\
\text { and liabilities by } \\
\text { public authorities }\end{array}$ & $\begin{array}{l}\text { No compensation from the public } \\
\text { authorities; facilitating market } \\
\text { mechanisms (insurance with } \\
\text { premiums depending on risk zones) }\end{array}$ & $\begin{array}{l}\text { No specific liability; in the } \\
\text { case of a flood, the State } \\
\text { steps in and compensates }\end{array}$ \\
\hline
\end{tabular}


justice in flood risk management, such as how to allocate flood protection measures (which areas to protect best), and who should pay for these measures. In Table 2, the four national flood risk management policies are compared in terms of the four criteria.

\subsection{England}

\subsubsection{Allocation of flood protection measures}

At the beginning of 2000, the New Labour government significantly redefined the flood policy in England. They partly redesigned the funding scheme and introduced an integrated-holistic view of flood risk management that also affected the allocation of flood protection schemes (Defra 2005). In the 1990s, the national government introduced the

Table 2 Comparing results of justice in the national flood risk management policy

\begin{tabular}{|c|c|c|c|}
\hline England & Austria & Germany & Netherlands \\
\hline \multicolumn{4}{|c|}{ Allocation of flood protection measures } \\
\hline $\begin{array}{l}\text { National funding based on } \\
\text { cost-benefit analysis } \\
\text { (utilitarianism) } \\
\text { Exemption in deprived } \\
\text { areas: structural } \\
\text { measures for the most } \\
\text { vulnerable people } \\
\text { (egalitarianism) }\end{array}$ & $\begin{array}{l}\text { Equal protection } \\
\text { standards (mostly } \\
1: 100 \text { ) without further } \\
\text { prioritisation } \\
\text { (egalitarianism) }\end{array}$ & $\begin{array}{l}\text { Equal protection standards } \\
\text { (mostly } 1: 100 \text { ) without } \\
\text { further prioritisation } \\
\text { (egalitarianism) } \\
\text { Transition from an } \\
\text { egalitarian model } \\
\text { towards a more } \\
\text { utilitarian approach } \\
\text { (utilitarianism) }\end{array}$ & $\begin{array}{l}\text { Differentiated } \\
\text { protection levels in } \\
\text { dike rings (up to } \\
\text { 1:10.000) } \\
\text { (utilitarianism) }\end{array}$ \\
\hline \multicolumn{4}{|l|}{ Process of allocation } \\
\hline $\begin{array}{l}\text { Decision mainly based on } \\
\text { experts' decision based } \\
\text { on cost-benefit analysis } \\
\text { (utilitarianism) }\end{array}$ & $\begin{array}{l}\text { Decision mainly based } \\
\text { on experts' decision } \\
\text { based on cost-benefit } \\
\text { analysis } \\
\text { (utilitarianism) }\end{array}$ & $\begin{array}{l}\text { Decision mainly based on } \\
\text { experts' decision based } \\
\text { on cost-benefit analysis } \\
\text { (utilitarianism) } \\
\text { Increasing centralisation } \\
\text { of decision-making } \\
\text { (utilitarianism) }\end{array}$ & $\begin{array}{l}\text { Elected Water boards } \\
\text { (egalitarianism) }\end{array}$ \\
\hline \multicolumn{4}{|c|}{ Share of costs for flood protection } \\
\hline $\begin{array}{l}\text { General state budget with } \\
\text { individual contributions } \\
\text { of landowners and } \\
\text { tenants } \\
\text { (utilitarianism) } \\
\text { Exemption with } \\
\text { communities falling } \\
\text { under partnership } \\
\text { funding: state budget } \\
\text { and fee proportional to } \\
\text { benefit } \\
\text { (liberalism) }\end{array}$ & $\begin{array}{l}\text { General state budget } \\
\text { with individual } \\
\text { contributions of } \\
\text { landowners and } \\
\text { tenants } \\
\text { (utilitarianism) } \\
\text { Local contributions } \\
\text { based on benefit } \\
\text { proportionality } \\
\text { (liberalism) }\end{array}$ & $\begin{array}{l}\text { Mainly state-financed } \\
\text { flood risk management } \\
\text { policy with different } \\
\text { responsibilities for } \\
\text { different water bodies } \\
\text { (utilitarianism) } \\
\text { Change towards more } \\
\text { national and state } \\
\text { funding } \\
\text { (egalitarianism) }\end{array}$ & $\begin{array}{l}\text { General state budget } \\
\text { with individual } \\
\text { contributions of } \\
\text { landowners and } \\
\text { tenants } \\
\text { (utilitarianism) }\end{array}$ \\
\hline $\begin{array}{l}\text { Possibility of private } \\
\text { insurance (state-funded), } \\
\text { because of no public } \\
\text { compensation } \\
\text { (utilitarianism) }\end{array}$ & $\begin{array}{l}\text { Usually, the state } \\
\text { voluntarily } \\
\text { compensates with } \\
\text { focus on most } \\
\text { vulnerable people } \\
\text { (egalitarianism) }\end{array}$ & $\begin{array}{l}\text { Usually, the state } \\
\text { voluntarily compensates } \\
\text { (egalitarianism) } \\
\text { Flooding in most places } \\
\text { insurable } \\
\text { (libertarianism) }\end{array}$ & $\begin{array}{l}\text { Usually, the state } \\
\text { voluntarily } \\
\text { compensates (areas } \\
\text { within the dike } \\
\text { rings) } \\
\text { (egalitarianism) }\end{array}$ \\
\hline
\end{tabular}


priority scoring system, in which the different flood risk management projects were ranked based on their benefit-cost ratio. The objective of the priority scoring was to identify if the project can be realised with the current national funds (to ensure the realisation of projects with highest benefits) and with effective use of public money. In 2010, the national government redesigned the allocation of flood protection measures by introducing the Outcome of Measures (OM). The OM approach ranks the selection of flood risk management schemes based on four elements. ${ }^{1}$ A further change came with the introduction of OM4, which focussed on requirements requested by the European Water Framework Directive (WFD) - the renaturation of rivers. With the introduction of the coalition government in 2010, we observed the latest step in the English flood risk management funding regime: the introduction of the partnership funding scheme in April 2011. The main reason for the introduction was the fiscal squeeze and state budget deficit. However, the partnership funding initiative is still in an experimental stage and not fully implemented for the whole country.

\subsubsection{Procedural justices: process of allocation}

The flood risk management system in England includes a wide range of different legislations and stakeholders. Main stakeholders are the Department of Environment, Food and Rural Affairs (Defra) and the Environment Agency (EA). Defra is responsible for the definition of the policy directions in England. EA has the operational responsibility, such as preliminary flood risk assessment, flood hazards and risk maps, realisation of flood defence schemes, flood warning and floodplain development advice. Further, the Internal Drainage Boards (IDB), Water industry and Highway Road Authorities are generally responsible for the ordinary water courses or pre-defined areas. Nevertheless, the process of allocation is mainly based on experts (strong top-down politics).

Within the introduction of the partnership funding scheme, also the politics of stakeholder engagement in the politics of flood risk management changed. Partnership funding encourages local actors to get actively involved in the decision process, which is a central objective of the new funding regime to encourage local actors, stakeholders and citizens to engage in flood risk management. In particular, a central objective is to encourage governing bodies at the local level to take over the responsibility from the national government (Thaler and Priest 2014; Begg et al. 2015; Thaler and Levin-Keitel 2016).

\subsubsection{Share of costs for flood protection measures}

Within partnership funding, the government grants the possibility of executing flood defence schemes, even if they do not match the necessary requirements for $100 \%$ funding. Today, approximately $75 \%$ of the projects are fully funded by the national government; the other $25 \%$ need additional funding from other parties. The central government has recognised the need for additional financial contributions from third parties (i.e., non-state actors, EU or county councils). These additional funding sources permit the country to realise more flood protection measures even if they do not match the necessary requirements for $100 \%$ funding.

Partnership funding anticipates a stronger engagement of non-state actors, such as local citizens, in the flood risk management discussion (Thaler and Priest 2014; Begg et al. 2015;

${ }^{1}$ OM 1 (economic benefits), OM 2 (households at risk), OM 3 (deprived areas at risk) and OM 4 (biodiversity). 
Thaler and Levin-Keitel 2016). Local actors and stakeholders have gained an important role in funding and in organising external contributions to close the financial gap for implementing structural flood protection. In England, for example, the contribution from third parties was approximately $£ 13$ million in the period from 2008 to 2011 ; approximately $£ 10$ million came from local authorities and approximately $£ 3$ million came from private actors (Committee on Climate Change 2012).

\subsubsection{Liability for damage}

Flood insurance plays a central role in the English flood risk management system (Lamond et al. 2009). In terms of compensation, landowners have no recourse for requesting compensation from the national government. The policy has functioned on a voluntary insurance system since 1961. The payment rates are based on policy agreements between the national government and insurance companies: a gentleman's agreement (PenningRowsell et al. 2014). However, the outcome was that the government has sent a false sense of security to the society with the consequence of encouraging the exposure within the country (Crichton 2002; Tarlock 2012). Furthermore, a central policy makes insurance coverage a prerequisite for obtaining a mortgage; this requirement has implications for selling the property. The availability of coverage depends on the following:

- Properties (private householders or businesses) in areas with a design level of 1:75 or less are available; the premium depends on the level of risk;

- Properties (private householders or businesses) in areas with a flood risk of 1:75 or more were only covered if the national authorities planned new or improved design level within 5 years.

\subsection{Austria}

\subsubsection{Allocation of flood protection measures}

The Austrian policy on flood risk management follows the 'classical' understanding of Central Europe. Overall, the policy aims to provide the same protection level to all citizens (1:100 design level). Therefore, the allocation of financing for flood protection measures also follows this principle; no distinction is made between the actual risk levels (including vulnerabilities); only the achievement of the design level is relevant (as in Germany) (Krieger 2012). Nevertheless, we observed a change in the flood risk management policy. Since the 1990s, the Austrian flood risk management has shifted slightly away from local flood protection schemes to a more holistic catchment management ideal (upstreamdownstream cooperations). The aim is to establish flood storages in the upper part of catchments to reduce vulnerability within the whole catchment instead of a local point (Thaler 2014; Thaler et al. 2016). In particular, downstream communities, which are more vulnerable within the catchment, benefit from this policy shift. This shift includes a 'safety transfer' from the upstream to the downstream communities and a 'money transfer' from the downstream to the upstream communities. The arrangements are defined based on a voluntary approach, although the interaction is based on formalised (pre-defined) rules, such as organisational structure, foundation, contract design, etc., as defined under the Austrian Water Act from 1959 (Austrian Government 1959). 


\subsubsection{Procedural justices: process of allocation}

In terms of procedural distribution, the inter-local cooperation has been transferring more responsibility and possibility to the local authorities, in contrast to the 'classical' management approach. Inter-local cooperation requires strong engagement of local authorities in the flood risk management discussion, such as planning, managing, designing and maintaining flood protection measures. Most of the inter-local cooperations demonstrate an active role in the planning and the strategic implementation process of flood risk management. The outcome is a stronger bottom-up approach. Nevertheless, the key problem within the inter-local cooperation approach is the power shift to a steering group that manages the cooperation. From the different examples investigated, we found that usually large communities are members of the steering group. The consequence is that small members often have less power in the overall decision process (Thaler 2014; Thaler et al. 2016).

\subsubsection{Share of costs for flood protection measures}

The flood risk management funding is based on national income tax as well as nationally guaranteed funding towards regional and local authorities. In general, the WLV (Austrian Service for Torrent and Avalanche Control) and BWV (Federal Water Engineering Administration) hold the responsibility for planning, designing and funding flood protection measures in Austria. The WLV is responsible for flood protection on the national level, whereas the BWV is an institution on the federal state level under the directive of the national level. Accordingly, two institutions at different at different spatial levels have the operational responsibility for flood protection. Together, they share the costs of a large financial contribution to flood protection measures (approximately $80 \%$ of the total costs). Section 6 of the law for subsidising water works ('Wasserbautenförderungsgesetz') determines that the costs for flood risk management have to be shared among the national WLV (around 40-50\%), state-level BWV (around 30-40\%) and local authorities and interests groups (20\% of total costs), such as landowners, public or private companies. According to the Austrian water law, partnership funding allows for sharing the local contribution among the members of the cooperation ('Wasserrechtsgesetz'). This includes that the inter-local cooperation is paying the necessary partnership funding.

\subsubsection{Liability for damage}

The Austrian water law does not provide a general right for flood protection measures that makes it possible for individual householders to claim a right for protection or security. The consequences of this are that individual householders may be required to take precautionary measures. Nevertheless, the main barriers and challenges of this model are the political systems that do not foresee an exclusion of flood protection. The Austrian policy decision makers understand flood risk management as a public good, which needs to be financed by general tax money (Holub and Fuchs 2009). However, if flood alleviation structures are built, the maintenance of these structures is the responsibility of local authorities. In terms of compensation, the different federal states have different rules governing the level of compensation, administration processes and legal exemptions in cases of social hardship (Holub and Fuchs 2009). However, the flood losses compensation 
scheme is based on public tax money and mainly excluded from property insurance policies. In generally, the range of compensation is between 30 and $50 \%$ of the total loss.

\subsection{Germany}

\subsubsection{Allocation of flood protection measures}

German flood protection is much entrenched in a design-level orientation. Germany aims to provide the same protection level to all citizens (1:100 design level) (Krieger 2012). This means that, except for the hinterland, the embankments of most rivers protect against a centennial flood. This is a basic principle not only in German regional planning, where the term originates, but it also has an impact on the distribution of tax incomes among the states (Wierer and Stauske 2005).

The allocation of finances for flood protection measures also follows this principle. Rather than the actual risk (including vulnerabilities), only the achievement of the design level is relevant (Krieger 2012). This undifferentiated allocation of flood risk management helps in understanding why, in Germany, a relatively large number of urban development projects takes place close to rivers (Hartmann 2011a, b). No differentiation is made between riparian and other areas (Kreibich et al. 2011). Nevertheless, the National Flood Protection Program from 2014 changes this situation in some respects. As a consequence of the flood events in 2013 in Eastern Germany and large parts of South Germany, flood protection measures have been prioritised (LAWA 2014). Specific weak spots in flood protection have been identified, and with a focus on critical national infrastructure, technical protection measures have been defined. Another criterion for prioritising measures in the National Flood Protection Program is the benefit of a certain measure for a certain area, taking into account the size of benefiting residential areas, commercial areas and the number of inhabitants for an extreme event (LAWA 2014). This resembles the emergence of a utilitarian approach to the allocation of flood protection measures in Germany (see also Table 2).

\subsubsection{Procedural justices: process of allocation}

For structural flood protection measures such as dikes, dams or retention polders, the Federal Water Act (WHG, Wasserhaushaltsgesetz) is the most important national law. Beyond this, flood protection is in the responsibility of the each Federal State (in total 16 different legislations). Each state released water laws that regulate the responsibility for flood risk management. An exception is the large rivers such as the Rhine, Elbe or Danube, which belong to the federation because they are federal waterways [Federal Act for Waterways (WaStrG), Section 1].

Section 40 WHG states that, in general, the owner of a water body is responsible for its maintenance (Section 40 WHG). Structural flood protection measures fall under the maintenance of water bodies (Section 39 and 67 WHG).

The states then divide the remaining water bodies into categories, called 'orders' ( 'Gewässerordnung'). For example, like most other federal water authorities, North RhineWestphalia determined that water bodies of the first order belong to the state. ${ }^{2}$ Those are usually the larger rivers in a state (Section $1 \mathrm{WaStrG}$ and Section 4 of the water law of North Rhine-Westphalia). For water bodies of the second order, North Rhine-Westphalia

${ }^{2}$ If they do not belong to the system of federal waterways. 
determined that ownership is linked to the ownership of adjacent land (if the water body is not real estate on its own). Other German states also define third-order water bodies as municipal water bodies. So, for most water bodies, some public institution is the responsible owner. Most states such as Saxony-Anhalt (Hartmann 2011c) or Saxony (Hartmann and Albrecht 2014) assign public bodies to be responsible for flood risk management, and only North Rhine-Westphalia has a particular system build on sophisticated water boards (Johann and Leismann 2014). The National Flood Protection Program has considerable impact on the federal organisation of flood protection, in that it aims at a stronger coordination of flood protection measures from the national level. This is the first time that flood risk management is attempted to be coordinated at the national level. Ultimately, it can be said that there is a tendency towards centralising the decision-making on the allocation of flood protection measures in Germany, triggered by recent flood events (see also Table 2).

\subsubsection{Share of costs for flood protection measures}

However, usually a public body finances the majority of the costs of structural measures. Section 40 WHG determines that the costs for flood protection measures can be shared among landowners and others who profit from the measure in question (Knopp 2010). The responsibility for flood risk management is assigned to the state level; hitherto, flood protection schemes that exceed the regional scale could not have been implemented due the central State funding (BMUB 2016). This led to insufficient realisation of upstream retention measures.

The National Flood Protection Program explicatively addresses the conflict of interests between upstream and downstream. The program wants to emphasise a principle of solidarity to finance measures in a catchment. Therefore, the national government set up a special fund, where more than 300 million Euro are foreseen for implementing measures. This fund is meant to compensate costs and benefits between upstream and downstream.

\subsubsection{Liability for damage}

Individual landowners cannot legally claim a right to a particular flood protection measure (not even against the one-in-a-hundred-years flood) (Breuer 2006). Legal claims may be made only if a governmental action was not proportional to the damages in question or in cases of negligence (Reinhardt 2004). In constitutional terms, landowners take all the benefits but also all the risks of landownership (Davy 2006).

There is no general entitlement to flood risk management, but once a dike has been built, water management agencies are liable for the maintenance of that dike (Hartmann 2009). This has several effects: first, water managers have an interest in the maintenance of dikes, which is positive for effectively defending against floods. But another effect is that landowners can rely on water management agencies-there is no special need to take action to realise precautionary measures.

In true practice, however, the state often intervenes in the case of disasters (Krieger 2012). For example, in 2002, a tax reform was postponed to alleviate the burden on flood victims (Deutscher Bundestag 2002). However, the state is not formally liable for individual damages (Reinhardt 2004). 


\subsection{The Netherlands}

\subsubsection{Allocation of flood protection measures}

In the Netherlands, water management has always been an essential issue in providing safe living conditions for the people (Needham 2007; Kabat et al. 2009; Hartmann and Spit 2012). A big issue - triggered by the large storm surge in 1953-is, of course, coastal flooding. But river floods also play an important role. In 1993, a major river flood event in the Netherlands initiated a paradigm shift in flood risk management away from a purely dike-dominated approach to comprehensive flood risk management (Hartmann 2012). However, dikes still remain the most important element of the national flood risk management (Wesselink et al. 2007).

Different flood protection levels exist in the Netherlands. Whereas most parts of the Randstad - the economic heart of the Netherlands, including the four big cities of Amsterdam, The Hague, Rotterdam and Utrecht-are protected against flood events of 1:10,000, less densely settled parts of the Netherlands are protected against flooding that occurs statistically once in 4000, 2000 or 1250 years (Kabat et al. 2009).

\subsubsection{Procedural justices: process of allocation}

For centuries, water boards have been essential institutions in the Netherlands (van der Cammen et al. 2012). These are local authorities that have evolved as bottom-up initiatives since the 13th century and are responsible for water control, including the maintenance of dikes (van Steen and Pellenbarg 2004). Currently, 26 of those water boards exist based on catchment-oriented boundaries (respectively dike rings). So, the administrative boundaries follow the water bodies, which is an important feature for all decisions regarding the allocation of protection measures. The water boards are composed of democratically elected representatives of public and private stakeholders (Heer et al. 2004). Water boards are considered to be the oldest democratic institutions in the Netherlands (Huisman 2002). The power of representatives depends on the benefit they receive from their activities (these benefits cover not only flood risk management but also water quality or quantitative water management). The collaboration between public and private entities is a typical way of organisation in the Netherlands ('Poldermodel') (Schreuder 2001). Besides the water boards, the Dutch Directorate-General 'Rijkswaterstaat' is the most important and central institution for water management in the Netherlands. It also builds on a long-lasting tradition, and it centrally governs and initiates all water-related issues with 'hegemony of the state' (Wiering and Crabbé 2006).

\subsubsection{Share of costs for flood protection measures}

Whereas water boards take care of local and regional flood protection measures, Rijkswaterstaat is responsible for national flood risk management. Rijkswaterstaat uses a general budget assigned by the government (via taxes) (Huisman 2002). Water boards cannot rely on subsidies from the national budget to pursue their tasks-they need to refinance their activities; therefore, water boards can make use of their authority to collect their own taxes (Kuks 2002; Rijkswaterstaat 2012).

As a result, tenants and landowners also pay a contribution to flood protection measures. Their contribution is collected in different taxes. The two most important taxes are the 
inhabitant tax and the property tax. Every tenant of a living accommodation pays for flood protection in the form of the inhabitant tax. In addition, landowners pay for flood risk management via the property tax. The tax is calculated based on the surface area of the individual property and the value of the buildings (appraised by the municipalities) (Huisman 2002).

\subsubsection{Liability for damage}

One important framing condition with respect to liability for flood damages in the Netherlands is that floods are, in general, not insurable. The whole Dutch system of flood risk management builds on the ideology that flooding just may not happen. This means that the options for private financial preventions are limited. Since 1995, it has been under consideration that the liability for flood damages be attributed to water boards and landowners (Kuks 2002).

\section{Discussion}

\subsection{Allocation of flood protection measures}

The English allocation of flood risk management policy includes a strong vein of utilitarianism - the maximisation of total benefits to society. One of the negative consequences of this policy direction is generating a moral hazards within the society. The government rewards moral hazards actions, because especially large urban developments (high number of exposure) will get secured by structural defence schemes (Tarlock 2012). In general, the selection of protection level is mainly based on the results from the benefit-cost ratio (Johnson et al. 2007). This fits the Dutch approach of differentiated flood protection levels for the Randstad and more rural areas. However, the English partnership funding policy indicate a shift towards a liberalist approach, where people with adequate financial resources are able to realise a protection scheme that benefits only them or a certain area (Thaler and Priest 2014). On the other hand, the Austrian clearly follows an egalitarian model within the allocation process in flood risk management. Influentially, the Austrian policy tries to redistribute the resources in flood risk management in order to equalise the distribution of investments (independently between rural or urban areas). The aim is to provide an equal-similar security-approach between the different regions. Equality is regarded here in the sense of Rawls idea of 'equality of outcome' (opposed to Friedman's 'equality of opportunity') (Sandel 2007). Although the German system also fits this egalitarian approach of equal protection standards, it seems to be in transition from an egalitarian model towards a more utilitarian approach, initiated by the National Flood Protection Program.

\subsection{Procedural justices: process of allocation}

The public administrations in the selected countries play the central role in flood risk management policy (top-down approach). These organisations are the key actors in the policy discussion and definition, where local stakeholders are mainly excluded from the discussion and decision-making process. The main reasons for this are their technical knowledge, their central role in funding and their permission power. Overall the local 
actors and stakeholder strategically depend on the national and regional authorities. Nevertheless, some examples with high local capacity and existing of space of engagement at regional or national level show a strong leadership at local level and bottom-up concepts and ideas. In particular, local knowledge and experiences play a role in the planning and implementation of flood risk management strategies. The local involvement in the discussion and decision process depends on the local capacity (capacity to act), such as resources (knowledge, financial, time), interest, social and cultural capital (Kuhlicke et al. 2011; Thaler and Priest 2014; Thaler and Levin-Keitel 2016). It strongly depends on the fact whether localities are able to ensure their interest and needs with national authorities.

The English flood risk management policy slightly opens the discussion process within the introduction of the partnership funding scheme. The implications are that local organisations have become more important in the English flood risk management policy. In terms of justice, this notion of equality of opportunity of different stakeholders is an important indicator for a more libertarian process. Dutch water management is organised from the bottom up, and water boards, which are backed by a strong state institution, are directly elected. This makes the Dutch system more egalitarian than the other models. In Germany, as well as in Austria, allocation decisions are mainly based on cost-benefit analysis (utilitarianism). The National Flood Protection Program in Germany leads to an increasing centralisation of decision-making, strengthening this utilitarian approach.

\subsubsection{Share of costs for flood protection measures}

The English system in the allocation of flood risk management is mainly based on the benefit-cost ratio (strong utilitarianism approach; see also Johnson et al. 2007). However, within the introduction of the outcome of measure system, the government begins to give a greater weight to deprived areas across the country, where the central government considered these areas as more worthy of receiving funds for flood management measures (shift towards a more egalitarianism thinking). Consequently, the national support were higher for deprived households, where they are least likely to be insured, less able to afford local protection measures and least likely to be able to recover from a flood event without additional welfare support. Therefore, a key change was that the aspects of justice played into the final decision process for the first time. Furthermore, the government excluded private businesses and infrastructure operators in the calculation-they had to manage their risk independently. Here, we observed a strong shift from an economic priority towards focusing on people. The latest step, within the introduction of the partnership funding, focuses on the method developed by the New Labour government but allows 'third parties' (non-state stakeholders or local authorities) to contribute to the flood risk management budget (depending on their income). This shift towards a beneficiary pays principle system clearly fits within the libertarian model (Watkinson et al. 2007). Germany and Austria probably lie on the other side of the spectrum, with a mainly state-financed flood risk management policy, although in many of the federal states, variations of state financing apply (whereas the National Flood Protection Program centralises the financing). It is worth mentioning that in Germany and the Netherlands a difference is made between national, regional and sometimes local water ways. Different institutions are responsible for the measures then. This nested hierarchy points towards a utilitarian system. However, as indicated earlier, the German system seems to change at the moment towards a more egalitarian scheme, because the National Flood Protection Program clearly states the goal of establishing a principle of solidarity among upstream and downstream. 


\subsection{Liability for damage}

The English liability for damage system includes a strong focus on private actors (insurance companies). Private insurance system clearly fits within the utilitarian model (Johnson et al. 2007), where the industry is focussing to ensure the greatest return to the shareholders. Further, the insurance system cannot fit to the egalitarianism approach, because usually the most vulnerable people at high risk are most likely uninsured (Lamond et al. 2009; Holub and Fuchs 2009; Penning-Rowsell et al. 2014). The interconnection between the private insurance system and the public policy of flood risk management can be understood as a dialectical interaction, where the private interests of householders and businesses-affordable insurance bills and access to mortgage- have become part of the general interests. In contrast in Austria where flood insurance has no significant influence in flood risk management policy, because the flood losses compensation scheme is based on public tax and mainly excluded from property insurance policies (Holub and Fuchs 2009). Further, the Austrian policy foresees a greater focus on the most social vulnerable people within the country. In particular, householders with low income get a higher support from the government. This clearly fits within the egalitarianism concept (Rawls 2005; Johnson et al. 2007; Sen 2010). Although there is no formal liability of the state for flood damages, the state usually steps into help victims of flood events. This fits an egalitarian approach. However, in addition to this, flooding in Germany is in almost all places insurable (within a scheme that includes also other natural hazards). In the Netherlands, in contrast, flooding is non-insurable. Also liability is barely discussed, because flooding is considered not an option at all. Most activities focus on technical flood protection measures to keep the water out-although this approach is very slowly changing due to the international debate on flood risk management. In recent election campaigns for the water boards, flooding of dike rings have been an issue. So, this issue is getting some awareness in the Netherlands.

\section{Conclusion}

Our study's results have yielded new insights regarding concepts of justice in the politics of flood risk management. In the four compared study sites, different notions of justice are applied to flood risk management. This paper compares the concept of justice reflected in four European countries' (Austria, Germany, England and the Netherlands) different approaches to flood risk management. In general, we can distinguish between an AngloSaxon justice approach (with a greater focus on Utilitarianism) and a continental European understanding of justice (with an emphasis on social justice). The greatest differences between England and continental Europe can be observed regarding issues of liability for damages and the allocation of flood risk management. Here, the English government follows a strongly technical decision-making process. The differences are mainly based on a historical development in the social contract between state and society (Johnson et al. 2007; Adger et al. 2013; Thaler and Priest 2014; Begg et al. 2015). However, each country has its own characteristic concept of justice. For example, Austrian flood risk management policy focuses on catchment-wide management as an ideal policy instrument to implement the European Floods Directive. In contrast, in the Netherlands and in Germany, the Government concentrates more on locally based flood risk management strategies (see also Hartmann 2011a, b and Thaler 2014). Moreover, the European Union has released a 
Directive calling for a more convergent approach all over Europe. This creates tensions because of the practical relevance of implementing the directive, notably the European Flood Risk Management Plans (Tempels and Hartmann 2014).

The allocation of flood protection measures differs in the four countries. In terms of justice, it is relevant to consider what is protected by the different approaches. Whereas flood protection measures in Germany are not an obligatory responsibility of the state, in reality, the allocation of flood protection measures follows the ideal of Rawls. No matter one's position in society or in terms of flood risk, everyone is protected equally. This concept is also applied in Austria, complemented by a CBA. The main consequence of the introduction of partnership funding in England is a strong involvement of local citizens in the planning and decision-making practices. On the one hand, we observed a 'privatisation' of responsibility, moving to non-state actors and stakeholders. On the other hand, the Austrian and German flood risk management systems include strong top-down decisionmaking practices, where experts from public administration or politicians design new flood risk management plans. This relationship is also characterised by a technocratic nature in these two countries, since civil servants have the main responsibility and workload in this relationship (Perkmann 2007). Meanwhile, the Dutch system incorporates more democratic elements (water boards are democratically elected bodies). In general, public administration is responsible for flood risk management; therefore, it is part of the executive estate of the state. This stands in contrast to the English flood risk management system, where, based on the Water Act from 1989 (UK Legislation 1989), private water companies are responsible for the urban drainage (Thaler and Priest 2014). An exception is the Dutch system of water boards, where water management authorities are composed of representatives of municipalities and industry (Hartmann and Spit 2012).

We conclude that no country has one clear-cut concept of justice; each of them incorporates elements from all concepts of justice. There also is not one prevailing approach to the allocation of flood protection measures, to the processes for allocation, the distribution of costs or the liability issues. This is important not only for the international collaboration in common catchments (which is least relevant for England), but also for the implementation of supranational legislation, notably European directives, such as EU Floods Directive or Water Framework Directive.

Acknowledgments Open access funding provided by University of Natural Resources and Life Sciences Vienna (BOKU). The research leading to these results has partly funding from the JPI-Climate project TRANS-ADAPT funded by the Austrian Federal Ministry of Science, Research and Economy (BMWFW), the French National Research Agency (ANR), the Ireland Environmental Protection Agency (EPA) and the Netherlands Organisation for Scientific Research (NWO) and Middlesex University, London.

Open Access This article is distributed under the terms of the Creative Commons Attribution 4.0 International License (http://creativecommons.org/licenses/by/4.0/), which permits unrestricted use, distribution, and reproduction in any medium, provided you give appropriate credit to the original author(s) and the source, provide a link to the Creative Commons license, and indicate if changes were made.

\section{References}

Adger WN, Quinn T, Lorenzoni I, Murphy C, Sweeney J (2013) Changing social contracts in climatechange adaptation. Nat Climate Change 3:330-333. doi:10.1038/nclimate1751

Austrian Government (1959) Wasserrechtsgesetz 1959 (WRG 1959) idF BGBI I Nr 14 2011, Vienna

Barraqué B (2014) The common property issue in flood control through land use in France. J Flood Risk Manag. doi:10.1111/jfr3.12092 
Begg C, Walker G, Kuhlicke C (2015) Localism and flood risk management in England: the creation of new inequalities. Environ Plan C. doi:10.1068/c12216

BMUB (2016) Fragen und Antworten zum Nationalen Hochwasserschutzprogramm. Retrieved from http:// www.bmub.bund.de/themen/wasser-abfall-boden/binnengewaesser/hochwasser/hochwasserschutzprog ramm/. Accessed 08 Mar 2016

Breuer R (2006) Die neuen wasserrechtlichen Instrumente des Hochwasserschutzgesetzes vom 3.5.2005. Nat Recht 28(10):614-623

Campbell T (2012) Theories of justice. Ashgate, Farnham

Committee on Climate Change (2012) Climate change-is the UK preparing for flooding and water scarcity? Retrieved from www.preventionweb.net. Accessed 26 Nov 2015

Crichton D (2002) UK and global insurance responses to flood hazard. Water Int 27(1):119-131. doi:10. $1080 / 02508060208686984$

Davy B (2006) Innovationspotentiale für Flächenentwicklung in schrumpfenden Städten. Retrieved from www.iba-stadtumbau.de. Accessed 26 Nov 2015

Department for Environment (Defra) (2005) Making space for water: taking forward a new government strategy for flood and coastal erosion risk management in England. Retrieved from http://archive.defra. gov.uk. Accessed 26 Nov 2015

Deutscher Bundestag (2002) Gesetzentwurf der Fraktionen SPD und BÜNDNIS 90/DIE GRÜNEN. Entwurf eines Gesetzes zur Änderung steuerrechtlicher Vorschriften und zur Errichtung eines Fonds 'Aufbauhilfe' (Flutopfersolidaritätsgesetz). Drucksache 14/9894. Berlin: Deutscher Bundestag

Doorn N (2015) The blind spot in risk ethics: managing natural hazards. Risk Anal 35(3):354-360. doi:10. 1111 /risa. 12293

Elster J (1992) Local justice: how institutions allocate scarce goods and necessary burdens. Russell Sage Foundation, New York

European Floods Directive (EC) (2007) On the assessment and management of flood risks. 23 October 2007. Off J Eur Union, L 288

Fuchs S (2009) Susceptibility versus resilience to mountain hazards in Austria - paradigms of vulnerability revisited. Nat Hazards Earth Syst Sci 9(2):337-352. doi:10.5194/nhess-9-337-2009

Fuchs S, Keiler M, Zischg A (2015) A spatiotemporal multi-hazard exposure assessment based on property data. Natural Hazards Earth Syst Sci 15(9):2127-2142. doi:10.5194/nhess-15-2127-2015

Gardoni P, Murphy C (2009) Capabilities-based approach to measuring the societal impacts of natural and man-made hazards in risk analysis. Nat Hazards Rev 10(2):29-37

Hartmann T (2009) Clumsy floodplains and the law: towards a responsive land policy for extreme floods. Built Environ 35(4):531-544

Hartmann T (2011a) Clumsy floodplains: responsive land policy for extreme floods. Ashgate, Farnham

Hartmann T (2011b) Contesting land policies for space for rivers: rational, viable, and clumsy floodplain management. J Flood Risk Manag 4(3):165-175. doi:10.1111/j.1753-318X.2011.01101.x

Hartmann T (2011c) Den Flüssen mehr Raum geben: umsetzungsrestriktionen in Recht und Praxis. Raumforsch Raumordn 69(4):257-268

Hartmann T (2012) Land policy for German rivers: making space for the rivers. In: Warner JF, van Buuren A, Edelenbos J (eds) Making space for the river: governance experiences with multifunctional river planning in the US and Europe. IWA Publishing, London, pp 121-133

Hartmann T, Albrecht J (2014) From flood protection to flood risk management: condition-based and performance-based regulations in German water law. J Environ Law 26(2):243-268. doi:10.1093/jel/ equ015

Hartmann T, Jüpner R (2013) Der Hochwasserrisikomanagementplan: Herausforderung für Wasserwirtschaft und Raumplanung. In Stamm J, Graw K-U (eds) Wasserbaukolloquium 2013. Technischer und organisatorischer Hochwasserschutz (pp 183-192). Dresden: Dresdner Wasserbauliche Mitteilungen

Hartmann T, Jüpner R (2014) The flood risk management plan-an essential step towards the institutionalization of a paradigm shift. Int J Water Gov 2(1):107-118. doi:10.7564/13-IJWG5

Hartmann T, Spit T (2012) Managing riverside property: spatial water management in Germany from a Dutch perspective. In: Hartmann T, Needham B (eds) Planning by law and property rights reconsidered. Ashgate, Farnham, pp 97-114

Hartmann T, Spit T (2015) Implementing the European flood risk management plan. J Environ Plan Manag. doi:10.1080/09640568.2015.1012581

Hayek FA (1991) The road to serfdom. Routledge, London

Heer JD, Nijwening S, de Vuyst S, Rijswick M, van Smit T, Groenendijk J (2004) Towards integrated water legislation in the Netherlands: lessons from other countries. Retrieved from www.uu.nl/faculty/leg. Accessed 26 Nov 2015 
Holub M, Fuchs S (2009) Mitigating mountain hazards in Austria: legislation, risk transfer, and awareness building. Nat Hazards Earth Syst Sci 9(2):523-537. doi:10.5194/nhess-9-523-2009

Huisman P (2002) How The Netherlands finance public water management. European Water Management. Retrieved from www.ewa-online.eu. Accessed 26 Nov 2015

Hunold C, Young IM (1998) Justice, democracy, and hazardous siting. Polit Stud 46(1):82-95. doi:10.1111/ $1467-9248.00131$

IPCC (2012) Managing the risks of extreme events and disasters to advance climate change adaptation. A special report of working groups I and II of the intergovernmental panel on climate change. Cambridge University Press, Cambridge

Johann G, Leismann M (2014) How to realise flood risk management plans efficiently in an urban area: the Seseke project. J Flood Risk Manag. doi:10.1111/jfr3.12075

Johnson CL, Penning-Rowsell E, Parker D (2007) Natural and imposed injustices: the challenges in implementing 'fair' flood risk management policy in England. Geograph J 173(4):374-390. doi:10. 1111/j.1475-4959.2007.00256.x

Kabat P, Fresco LO, Stive MJF, Veerman CP, van Alphen JSLJ, Parmet BWAH et al (2009) Dutch coasts in transition. Nat Geosci 2(7):450-452. doi:10.1038/ngeo572

Knopp G-M (2010) Das neue Wasserhaushaltsrecht: WHG-Novelle 2010. Beck, München

Kreibich H, Seifert I, Thieken AH, Lindquist E, Wagner K, Merz B (2011) Recent changes in flood preparedness of private households and businesses in Germany. Reg Environ Change 11(1):59-71. doi:10.1007/s10113-010-0119-3

Krieger K (2012) Norms, structures, procedures and variety in risk-based governance: the case of flood management in Germany and England. Jerus Papers Regul Gov 2012(47):1-33

Kuhlicke C, Steinfuehrer A, Begg C, Bianchizza C, Bruendl M, Buchecker M, De Marchi B, Di Masso Tarditti M, Hoeppner C, Komac B, Lemkow L, Luther J, McCarthy SS, Pellizzoni L, Renn O, Scolobig A, Supramaniam M, Tapsell S, Wachinger G, Walker G, Whittle R, Zorn M, Faulkner H (2011) Perspectives on social capacity building for natural hazards: outlining an emerging field of research and practice in Europe. Environ Policy 14:804-814. doi:10.1016/j.envsci.2011.05.001

Kuks S (2002) The evolution of the national water regime in The Netherlands. Retrieved from www. euwareness.nl. Accessed 26 Nov 2015

Lamond JE, Proverbs DG, Hammond FN (2009) Accessibility of flood risk insurance in the UK: confusion, competition and complacency. J Risk Res 12(6):825-841. doi:10.1080/13669870902768614

LAWA (2014) Zusammenfassende Analyse der Ergebnisse der vom Hochwasser 2013 betroffenen Flussgebietsgemeinschaften beschlossen auf der 147. LAWA-VV am 27./28. März 2014 in Kiel, Kiel

Legislation UK (1989) Water Act 1989. UK Parliament, London

Lu F, Ocampo-Raeder C, Crow B (2014) Equitable water governance: future directions in the understanding and analysis of water inequities in the global South. Water Int 39(2):129-142. doi:10.1080/02508060. 2014/896540

Mabry L (2009) Case study in social research. In: Alasuutari P, Bickman L, Brannen J (eds) The SAGE handbook of social research methods. SAGE, London, pp 214-227

May L, Morrow P (2012) Procedural justice. The library of essays on justice. Ashgate, Farnham

Mazzorana B, Levaggi L, Keiler M, Fuchs S (2012) Towards dynamics in flood risk assessment. Nat Hazards Earth Syst Sci 12(11):3571-3587. doi:10.5194/nhess-12-3571-2012

McKinnon C (2009) Runaway climate change: a justice-based case for precautions. J Soc Philos 40(2):187-203. doi:10.1111/j.1467-9833.2009.01446.x

Mill JS (2010) Utilitarianism, liberty and representative government. Wildside Press, Milton Keynes

Moellendorf D (2009) Justice and the assignment of the intergenerational costs of climate change. J Soc Philos 40(2):204-224. doi:10.1111/j.1467-9833.2009.01447.x

Neal MJ, Lukasiewicz A, Syme GJ (2014) Why justice matters in water governance: some ideas for a 'water justice framework'. Water Policy 16:1-18. doi:10.2166/wp.2014.109

Needham B (2007) Dutch land use planning: planning and managing land use in the Netherlands, the principles and the practice. SDU, The Hague

North DC (1990) Institutions, institutional change, and economic performance. The political economy of institutions and decisions. Cambridge University Press, Cambridge

Ostrom E (1986) An agenda for the study of institutions. Public Choice 48(1):3-25

Patrick MJ (2014) The cycles and spirals of justice in water-allocation decision making. Water Int 39(1):63-80. doi:10.1080/02508060.2013.863646

Penning-Rowsell EC, Priest S, Johnson C (2014) The evolution of UK flood insurance: incremental change over six decades. Int J Water Resour Dev 89(4):694-713. doi:10.1080/07900627.2014.903166

Perkmann M (2007) Construction of new territorial scales: a framework and case study of the EUREGIO cross-border region. Reg Stud 41(2):253-266. doi:10.1080/00343400600990517 
Rawls J (2005) A theory of justice. Harvard University Press, Cambridge

Reinhardt M (2004) Hochwasserschutz zwischen Enteignungsentschädigung und Amtshaftung. Nat Recht 26(7):420-429

Rijkswaterstaat (2012) Flood risk and water management in The Netherlands: A 2012 update. Retrieved from http://wetten.overheid.nl. Accessed 26 Nov 2015

Roemer JE (1987) Egalitarianism, responsibility and information. Econ and Philos 3(2):215-244. doi:10. $1017 /$ S026626710000290X

Sandel MJ (2007) Justice: a reader. Oxford University Press, Oxford

Schreuder Y (2001) The polder model in Dutch economic and environmental planning. Bull Sci Technol Soc 21(4):237-245. doi:10.1177/027046760102100401

Sen A (2010) The idea of justice. Penguin, London

Tarlock DA (2012) Takings, water rights, and climate change. 36 Vt. L. Rev. 731. http://scholarship. kentlaw.iit.edu/cgi/viewcontent.cgi?article=1675\&context=fac_schol. Accessed 02 Mar 2016

Tempels B, Hartmann T (2014) A co-evolving frontier between land and water: dilemmas of flexibility versus robustness in flood risk management. Water Int 39(6):872-883. doi:10.1080/02508060.2014. 958797

Thaler T (2014) Developing partnership approaches for flood risk management: implementation of interlocal co-operations in Austria. Water Int 39(7):1018-1029. doi:10.1080/02508060.2014.992720

Thaler T, Levin-Keitel M (2016) Multi-level stakeholder engagement in flood risk management - a question of roles and power: lessons from England. Environ Sci Policy 55(1):292-301. doi:10.1016/j.envsci. 2015.04.007

Thaler T, Priest S (2014) Partnership funding in flood risk management: new localism debate and policy in England. Area 46(4):418-425. doi:10.1111/area.12135

Thaler T, Priest S, Fuchs S (2016) Evolving interregional co-operation in flood risk management: distances and types of partnership approaches in Austria. Reg Environ Change 16(3):841-853. doi:10.1007/ s10113-015-0796-z

van der Cammen H, Klerk LAD, Dekker G, Witsen PP, O’Loughlin M (2012) The selfmade land: culture and evolution of urban and regional planning in The Netherlands. Spectrum, Houten

van Steen PJ, Pellenbarg PH (2004) Water management challenges in the Netherlands. Tijdschr Econ Soc Geogr 95(5):590-598

Varian HR (1975) Distributive justice, welfare economics, and the theory of fairness. Philos Public Aff 4(3):223-247

Walker G (2009) Beyond distribution and proximity: exploring the multiple spatialities of environmental justice. Antipode 41(4):614-636. doi:10.1111/j.1467-8330.2009.00691.x

Walker G, Burningham K (2011) Flood risk, vulnerability and environmental justice: evidence and evaluation of inequality in a UK context. Crit Soc Policy 31(2):216-240. doi:10.1177/0261018310396149

Watkinson AR, Cornell SE, Tinch R (2007) Sustainability of flood risk management responses. In: Thorne CR, Evans EP, Penning-Rowsell E (eds) Future flooding and coastal erosion risks. Thomas Telford, London, pp 461-474

Wesselink A, Bijker WE, de Vriend HJ, Krol MS (2007) Dutch dealings with the delta. Nat Culture 2(2):188-209

Wierer E, Stauske J-C (2005) Gleichwertige Lebensverhältnisse. Retrieved from http://www.landtag.nrw.de. Accessed 26 Nov 2015

Wiering M, Crabbé A (2006) The institutional dynamics of water management in the low countries. In: Arts B, Leroy P (eds) Institutional dynamics in environmental governance. Springer, Dordrecht, pp 93-114

Zwarteveen MZ, Boelens R (2014) Defining, researching and struggling for water justice: some conceptual building blocks for research and action. Water Int 39(2):143-158. doi:10.1080/02508060.2014.891168 